CORRECTION

\title{
Correction: Supportive treatment of vascular dysfunction in pediatric subjects with obesity: the OBELIX study
}

Luca Pecoraro (D), Thomas Zoller, Richard L. Atkinson, Fulvio Nisi, Franco Antoniazzi, Paolo Cavarzere, Giorgio Piacentini and Angelo Pietrobelli (iD

(c) The Author(s) 2022

Nutrition and Diabetes (2022)12:5 ; https://doi.org/10.1038/s41387-022-00183-6

Correction to: Nutrition and Diabetes 2022;12:1-8 https://doi.org/ 10.1038/s41387-021-00180-1, published online 10 January 2022

The original version of this article unfortunately contained a mistake. Due to a typesetting error, the author names were interchanged. We apologize for the error. The original article has been corrected.

\begin{abstract}
(c) (i) Open Access This article is licensed under a Creative Commons Attribution 4.0 International License, which permits use, sharing adaptation, distribution and reproduction in any medium or format, as long as you give appropriate credit to the original author(s) and the source, provide a link to the Creative Commons license, and indicate if changes were made. The images or other third party material in this article are included in the article's Creative Commons license, unless indicated otherwise in a credit line to the material. If material is not included in the article's Creative Commons license and your intended use is not permitted by statutory regulation or exceeds the permitted use, you will need to obtain permission directly from the copyright holder. To view a copy of this license, visit http://creativecommons. org/licenses/by/4.0/.
\end{abstract}

(c) The Author(s) 2022 